Article

\title{
Can User Innovation Grow a Firm? The Case of the Korean Smart Media Industry
}

\author{
Cheongho $\mathrm{Na}^{1}$, Eungdo Kim ${ }^{2, *}$ and Kwangsoo Shin ${ }^{2}$ \\ 1 Technology Management, Economics and Policy Program, College of Engineering, \\ Seoul National University, Seoul 08826, Korea; chunghonice@snu.ac.kr \\ 2 Department of Biomedical Convergence, College of Medicine, Chungbuk National University, \\ Cheongju 28644, Korea; sksidea@gmail.com \\ * Correspondence: edkim@chungbuk.ac.kr
}

Received: 29 August 2019; Accepted: 27 September 2019; Published: 2 October 2019

check for updates

\begin{abstract}
With the rapid development of information and communications technology (ICT), smart society has arrived. The emergence of smart media has changed the user's role. Broader communication coverage, faster Internet speeds, and an expanding application market promote user participation. Therefore, the role of users in innovation has become more important than ever. In this rapidly changing environment, it has become important for firms to consider the role of users when developing innovation strategies. It is hard for a firm to maintain all abilities and resources amid this sudden change; therefore, firms have to develop their strategy considering the user's role. For that reason, firms need to network with universities, researchers, firms, and users from the open innovation perspective. This study divides firm strategy into exploitation and exploration strategies in the value chain and identifies the effects of utilization strategy, exploration strategy, and the role of users in the smart media industry on firm performance.
\end{abstract}

Keywords: User innovation; open innovation; exploitation and exploration strategy; smart media industry; innovation factors

\section{Introduction}

\subsection{Background of the Study}

In the past 10 years, the concept of open innovation has received wide attention from academics and practitioners. The concept of open innovation has been used as a strategy by firms [1-4]. A company may not have the ability to conduct business and implement strategies in an environment featuring the simultaneous development of many technologies. Therefore, it is important for a company to have good relationships with other companies. In addition, ICT has developed extensively compared to 10 years ago, meaning that the surrounding environment has changed greatly. One of the characteristics of this changed environment is technological convergence. That means inter-industry convergence, as well as the fusion of ICT [5-7]. People can now use devices such as smartphones, smart TVs, smart tablets, and smart watches. This is a manifestation of technological convergence.

As the ICT environment continues to evolve and change, more companies will become unable to provide all required resources and capabilities themselves, and relationships with network entities that can exchange the necessary resources and capabilities will become more important. In addition, with the continuous development of ICT technology, the development of media services has changed modern society from a smart information society to a smart society $[7,8]$. This includes changes for various industries based on ICT. One is the technological convergence phenomenon, which promotes convergence among industries beyond ICT convergence. The other is that smart devices such as smart 
phones, smart TVs, and tablets generate innovation throughout society, and change and reinforce the roles of the people who use them $[9,10]$. For example, in a smart society, users can deliver content through the app store and have a greater impact on products and services than they had previously through communication channels such as SNS.

\subsection{Aim of the Study}

In order to achieve better performance in a smart society, users should be recognized as having a changed and strengthened role, and reflected as subjects of the innovation system $[7,9,11]$. Social networking platforms such as Facebook and Twitter have helped users to establish personal networks. These platforms have helped users have a greater impact on other users, and user feedback on products and services has affected not only research and development (R\&D), but also the proliferation of products and services [12]. In addition, the concept of lead users who participate in development to resolve the needs and problems of existing products and services has been suggested [13], with the argument that these users will become more widespread in the future. In addition, users can play a more active role, such as by building innovation networks to support products or services developed by other users.

However, there have been a few studies showing that the characteristics of such a smart society are not reflected in firm strategies. The present study first classified firm strategy into exploitation and exploration strategies. Exploitation strategy is defined as activity aiming to improve products and markets, and exploration strategy is defined as technological innovation activity aimed at entering a new market [14-16]. In this study, an extension of a conference paper [17], we examined the effects of the two existing strategies on firm performance, and considered the role of users in relation to firm performance. Through this empirical analysis, we discovered implications for firms' strategies and industrial policies regarding the role of users in the smart media era.

\section{Literature Review}

\subsection{Open Innovation Strategy in the Smart Era}

The ICT-technology-based smart era has caused other environmental changes beyond those mentioned above. First, in a smart society, there exists a phenomenon of vertical and horizontal fusion in value chain through technological convergence. Previous studies $[7,9,18]$ have mentioned that firms and customers drive the industry in new ICT environment. Therefore, they have made the relationship which relies on each other more closely compared to industries in the past. This series of changes has brought changes in ordinary people's lifestyles. Smart devices, the fruit of ICT technology development, are the entry to smart society. The smartphone in particular brought changes in content spreading methods, service improvement, and technology. In other words, the combination of device, service, and content has spread media service and influenced related industries, and the role of end users who actually use the devices is significant. Previously, "users" meant end users, but in the smart era, "users" includes both people and organizations, and the social positions of people who get advantages from using products and services. As a result, the smart era is extending and strengthening the role of users $[6,7]$.

\subsection{Open Innovation and Firm Strategy}

In discussing the paradigm of open innovation, inside-out processes were emphasized in [1]. Open innovation is about creating a new market by presenting new technology from inside to outside and increasing the technology. In this case, it exists as licensing, technology trading, spinoffs, and platform releases. However, internet-based society is accelerating the outside-in process. The outside-in process includes technology trading, joint research, venture investment, and user innovation. In the strategic frame of open innovation, firms manage the entire process of R\&D 
and commercialization in different areas such as cooperation with industry and academia, licensing, spinoffs, venture investment, and user innovation.

Inside-out strategy is important to firm performance in terms of using internal sources for outside function. In addition, the internet-based knowledge of society's environmental changes and industry needs to extend the viewpoint of open innovation, and relate to outside-in strategy. The lifecycles of products and services have been shortened. Hence, it is getting harder for single firms to have full capacity; even if a single firm has full capability for its products or services from development to extension, taking on uncertainty is more difficult. In the rapidly changing and innovating high-tech industry, a huge cost is required to attain and hold technological competency. Because of the high uncertainty, it is challenging for a firm to control its entire process [19-21]. Thus, from the viewpoint of outside-in innovation, strategic alliance is one of a firm's options. Through collaboration, firms reduce cost and uncertainty while gaining new technology. Strategic alliances are about co-development, sharing, and exchanging products, technology, or services among firms [22-24]. These alliances show network characteristics, and the amount of collaboration is related to the results of innovation $[25,26]$.

Many studies have been carried out using users as actors for open innovation at the industrial or firm level. In Bhatt and Altinay [27], it was argued that social firms are able to expand social innovation by engaging end users in new service and product development stages. Research has also been conducted on how ethnic minority companies grow through the trust of their customers [28]. As the participation of users is perceived to be important, there have also been studies on factors that restrict user participation. It was suggested in [29] that traditional service industries such as the hotel industry tend to restrict customer participation due to organizational factors such as management structure and culture, and tend to view customer information as limited or biased.

As mentioned above, firms rely on users to supplement their sources and capability to reduce uncertainty, alongside existing outside-in innovation such as between firms, firms with academia, and between institutes. Users can replace or complement a firm's sources and capabilities, so the firm can understand users' value as part of a network and use them wisely.

\subsection{User Role from the Viewpoint of Open Innovation}

Users can use hardware and software more easily than ever. As a result, this strengthened ability makes innovation by users easier, and developing technology lowers the cost of being involved in innovation. Moreover, internet-based communities make sharing of opinions, information, and devices among personal users possible, and firms cooperate with it because they understand their value [30]. A firm's innovation activities and strategies are increasingly connected to more customers. The new ICT environment proposed in $[7,17]$ includes both manufacturing and service industries, and revealed that the environment of the new ICT industry is in closer contact with customers. Innovation in the service sector differs from innovation through technological development in manufacturing, such as product design and dissemination [31]. There is also a significant relationship between innovation and good relationships with customers in the service sector [32]. Recent studies have argued that innovation in the public services sector has proven to be more effective in promoting innovation by leveraging people's capabilities and knowledge [33].

Users in the smart era are becoming active and taking the main role in innovation. Thus, the user's role has become clearer and wider and with more influence since the smart era began. In von Hippel [34], the innovation of the information era was explained as the beginning of a new innovation type-the concept of user innovation. User innovation means improving or developing products or services to solve problems and meet users' needs while using existing products or services [13].

Users can take a beta tester role to adjust innovation standards before products are released [35]. This feedback ensures that the product or service meets customers' needs, and reduces the uncertainty of demand. In this way, firms can forecast and stabilize the demand for products or services. In Rogers [36], this user role was called the "early adopter", and early adopters have influenced the majority of the early and late periods. This role strengthened by connectivity, and reciprocity is emphasized in this 
environment. Firms fill the deficiency through contracts, because they do not have the full resources and capability needed from the development to the dissemination stage of products or services.

From the viewpoint of user innovation, another user type, called the "lead user", was defined in [37]. Reflecting their needs, users participate not only passively, but actively in the R\&D or ideation process. Firms use this advantage to build up their resources and capability, which has a positive impact on business performance.

\subsection{Exploitation and Exploration Innovation and User Roles}

In He and Lee et al. [14,26], exploitation and exploration innovation strategies were separated as part of the strategies affecting business performance. The simultaneous pursuit of exploitation and exploration contributes to a growth of average sales, and exploitation and exploration innovation strategies have positive effects on product innovation intensity. Additionally, the exploitation innovation strategy has positive effects on the process of innovation intensity. The authors separated firms into groups using both exploitation and exploration innovation, just exploitation innovation, just exploration innovation, and others for ANOVA analysis. The results showed that performance in the group using exploration innovation was higher than that in the groups using both innovation and exploitation innovation. On the other hand, the performance of groups using both innovations was lower than that of the other groups. A positive influence between exploitation and exploration on firm performance in the biotechnology industry was found in [38]. The authors defined the basic and drug research stages as exploration processes, the commercializing stage as utilization, and each process as a cycle of one product. They then suggested that the product process be integrated by factor analysis as exploration innovation first, then product development, exploitation innovation, and commercialization. How the weight of exploitation and exploration influence ROA (return on assets) was studied from the viewpoint of an alliance portfolio in [39]. The authors considered the age of the firm, strategic choice, and growth of the industry as controlled variables.

In this research, He and Wong's work was used to study existing strategies influencing business performance, considering the correlation of performance with exploitation and exploration at the firm level as the strategy. Furthermore, considering industrial specificity, the user role was taken as a network object, and how the strengthened and changed user role impacted performance was measured. Likewise, other exogenous variables have influenced the correlation between performance and exploitation innovation, exploration innovation, and the user's role were controlled to estimate the effect properly.

\section{Research Framework and Hypothesis}

This research studied the influence of exploitation and exploration strategies on business performance to analyze firm strategy and the effect of the user role on business performance. To appropriately measure the effect, other variables, including firm strategy, age of the firm, R\&D concentration, and market structure were considered [39-42]. Figure 1 shows the research framework. 


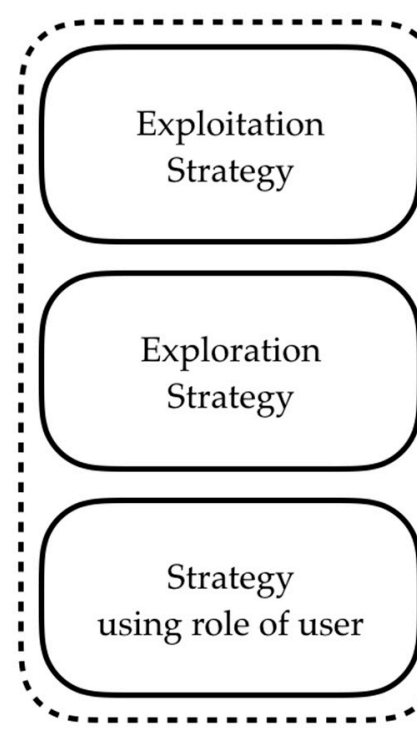

Firm Strategy

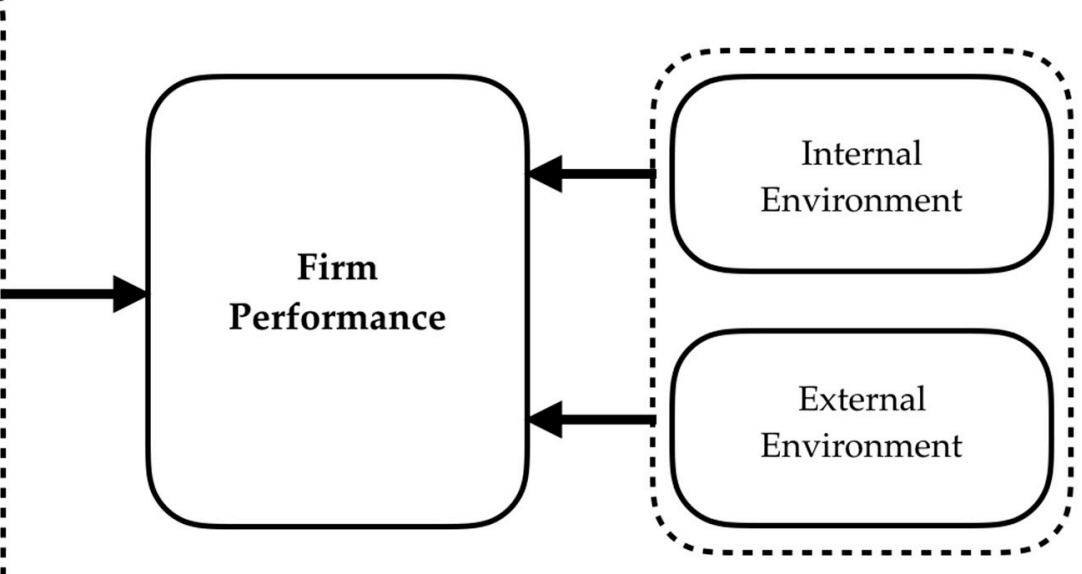

Environment

Figure 1. Research framework.

\subsection{Exploitation Strategy and Firm Performance}

In order to investigate the effect of exploitation strategy on performance, we examined the factors of the strategy. First, the elements of exploitation strategy as examined in the literature are license sales, improved products or services, and marketing agreements [15,42,43]. The use of resources was analyzed in [44], including licensing and marketing agreements used to engage contracts and increase efficiency. In particular, the smart media industry can be influenced by marketing agreements because of various applications such as the application market, marketing using SNS, and social commerce. In addition, He [14] classified improved products or services as exploitation strategies, and found that they had a positive correlation with firm performance.

Hypothesis 1. The more license sales there are, the more the firm's performance will improve.

Hypothesis 2. The more product or service improvement there is, the more the firm's performance will improve.

Hypothesis 3. The more marketing agreements there are, the more the firm's performance will improve.

\subsection{Exploration Strategy and Firm Performance}

Similarly, to explore the impact of the exploration strategy on firm strategy, we looked at the elements of exploration strategy, which also represent the characteristics of exploration strategy. First, the elements of exploration strategy that have been examined in the literature are patent or copyright applications, market-first products or services, and R\&D agreements. Exploration is related to new ideas and refers to patents and copyrights, as explained in [45]. In addition, Koza and Lewin [43] extended the definition of strategic contractual relationships by identifying new products or services that are marketed for the first time, such as research, as well as R\&D and technical agreements. As reported in [39], when the proportion of exploration in an industry with a high growth rate is large, it positively affects firm performance. Smart media is a high-growth industry, and, due to the nature of the industry, a product's ecological cycle is so short that companies can achieve good results through a continuous exploration strategy. Therefore, the exploration strategy of a company will have a positive correlation with its performance.

Hypothesis 4. The more patent or copyright applications there are, the more the firm's performance will improve. 
Hypothesis 5. The more first products on the market there are, the more the firm's performance will improve.

Hypothesis 6. The more RED agreements there are, the more the firm's performance will improve.

\subsection{User Role and Firm Performance}

The user's role in the smart media industry can be described by a company strategy that utilizes user innovation from the perspective of open innovation. With technological advances and changes in the industry environment, the role of users is gradually expanding or emerging, and this role has been defined in previous research. A study on five radical innovation projects in the field of medical technology [45] reported that users play a role as co-developers, and noted that this role is beneficial to projects. We have also seen users as a beta tester pool for products, providing feedback, and Riggs and von Hippel [46] further defined "lead user" as the role of the active user. A study on the efficiency and effectiveness of innovation using leading users [34] discussed the positive role of these users in the development of new products. Additionally, the development process of users has been shown to extend product life and contribute to the growth of original product sales [47]. In addition, with the introduction of the smart age, it has become easier for users to communicate their opinions using smart devices, and their influence is greater than ever before. This suggests that the influence of early adopters, as claimed in [36], has become stronger. In particular, the online community, which plays a central role in consumption in modern society, accelerates dissemination, and consumers dominate as both the subject and object in the evaluation of products and services. The acceptance of innovation has an influence. Therefore, the role of the forwarder will have a greater impact on the proliferation of products or services in the future than ever before. User feedback also reflects consumer needs before products or services are released, thereby reducing uncertainty in demand. Companies can gain stability of their products or services through demand forecasts [35]. In this way, the changed and strengthened role of users is a feature of the smart media industry, as described above, and user roles positively affect company performance. In addition, the smart media industry includes many startup companies that use users, which will increase the efficiency of their capabilities and resources and replace scarce resources and capabilities with users. In the R\&D stage, companies use the roles of users to obtain positive effects in developing products or services. Users' mutuality and connectivity play a role in promoting the dissemination of products and services. Users will have a positive impact on the performance of the company.

Hypothesis 7. Users may have a positive influence on firm performance.

Hypothesis 8. The leading user role may have a positive influence on firm performance.

Hypothesis 9. The early adopter role may have a positive influence on firm performance.

Hypothesis 10. The feedback provider role may have a positive influence on firm performance.

\section{Methodology}

\subsection{Data and Empirical Model}

This research was based on data from a 2012 to 2014 survey of Korean smart media industry related firms. The sample firms were selected from the list of content, hardware, software, and network service firms maintained by the Korea Creative Content Agency. Among 895 firms provided, we gathered survey responses from 118 firms-a 13\% response ratio. Data on seven network service providers were eliminated because the samples were too small to be representative. From data on 111 firms, once samples with missing data were excluded, 107 samples were fixed as the final dataset. In this study, two models were used for analysis. The user role was set as one scale with Model 1 and put on 
the survey separately. The user role was subdivided in Model 2 to show how each role contributes to performance.

1. Model 1: ASGR $=\mathrm{a} 1 \times$ AGE $+\mathrm{a} 2 \times \mathrm{RDINT}+\mathrm{a} 3 \times \mathrm{HHI}+\mathrm{a} 4 \times \mathrm{PC}+\mathrm{a} 5 \times \mathrm{MARF}+\mathrm{a} 6 \times \mathrm{RDAL}+$ a7 $\times$ LIC + a $8 \times$ IMPS + a9 $\times$ MARAL + a10 $\times$ USERTT

2. Model 2: ASGR $=\mathrm{a} 1 \times \mathrm{AGE}+\mathrm{a} 3 \times \mathrm{RDINT}+\mathrm{a} 3 \times \mathrm{HHI}+\mathrm{a} 4 \times \mathrm{PC}+\mathrm{a} 5 \times \mathrm{MARF}+\mathrm{a} 6 \times \mathrm{RDAL}+$ a7 $\times$ LIC + a $8 \times$ IMPS + a9 $\times$ MARAL + a10 $\times$ USERRD + a11 $\times$ USERFD + a12 $\times$ USEREA

\subsection{Variables}

This research used 3 years' average sales growth as the dependent variable for firm performance. The survey showed that the average time for products or services to go from ideation to production and sales was less than 3 years in $94.8 \%$ of firms. It also showed the Korean smart media industry's short project period. Therefore, 3 years of average sales growth was appropriate.

Exploitation and exploration are general and broad concepts. Therefore, we adopted existing firm strategies to fix these two concepts for exploitation and exploration strategies. Variables were set using past studies. First, regarding the variables of exploitation strategy, license sales and marketing agreements were classified as exploitation in [48], because license sales use supplemental knowledge and resources and marketing agreements are used as signed contracts. Regarding improved products or services, He [14] classified quality improvement related to process innovation as exploitation. To measure these three variables, target firms were asked in the survey about quantity of license sales, signing of marketing agreements, and improved products or services.

Contracts among subjects for new technological R\&D such as R\&D agreements, technical agreements, etc., were explored in [43]. Patent and copyrights were classified as exploration in [44]; improved products or services were classified as exploration innovation strategy in [9]. To measure these three variables, target firms were asked in the survey about quantities of patents and copyrights, the first product or service on the market, and R\&D contract signing.

Strengthened or newly created user roles were described in [18]. The first example was the user feedback role. Users react to certain products or services, especially when beta testing new products in the ICT system $[7,35]$. Second, users who get actively involved in the R\&D process are content providers in the smart media industry [9,18]; in von Hippel [37] those users were called "lead users". The third user role is sharing and providing information and knowledge. These users were called "early adopters", who gave information and knowledge to the majority of users in the early and last period. These roles were explained in the survey to find out whether firms were using them as a strategy, and if they affected business revenue. Participants could evaluate the user roles using a five-point scale, from 0 to 4 .

We attempted to control for the company's internal and external characteristics (size, age, R\&D investment ratio, market structure, and industry dummy), since previous studies have suggested that these variables can have an inconsistent impact on innovation performance.

Firm age is an important indicator of a firm's accumulated resources and capability; therefore, a firm's age has a significant role in its strategy and performance [2,3,7]. Startup firms do not initially have the resources and capability they need; these are accumulated as firms mature. However, startup firms can pull resources and capability, capital, marketing, and spread from other firms [49]. The correlation between a firm's cooperation of exploitation and exploration and the influence of its age on performance was addressed in [39].

$R \& D$ concentration shows a firm's R\&D status. The value of total R\&D expenses divided by sales is the $R \& D$ concentration ratio $[24,26,50]$. The present research measured the value of expenses and sales in 3 years. If the R\&D concentration ratio is high, the possibility of obtaining technology and innovation resources increases, which has a positive effect on business performance [42,51].

Most research studying the correlation of a firm's oligopoly or monopoly with performance has used the market concentration ratio as a representative variable of market structure. The Herfindahl-Hirschman index (HHI) is a helpful indicator able to measure the market concentration 
ratio and the monopolism of the market. As stated in [3,43], a firm's innovative activity has an inverted U-shaped correlation with market concentration. HHI is an accurate method of measuring market concentration. A summary of variables is presented in Table 1.

Table 1. Summary of variables.

\begin{tabular}{|c|c|c|c|}
\hline Type & \multicolumn{2}{|c|}{ Variables } & Explanation \\
\hline $\begin{array}{l}\text { Dependent } \\
\text { variable }\end{array}$ & Performance & ASGR & Average growth rate for 3 years \\
\hline \multirow{9}{*}{$\begin{array}{l}\text { Independent } \\
\text { variable }\end{array}$} & \multirow{3}{*}{ Exploitation } & LIC & Average number of licensing-out contract for 3 years \\
\hline & & MARAL & Average number of marketing agreement for 3 years \\
\hline & & IMPS & Average improvement of product or product line for 3 years \\
\hline & \multirow{3}{*}{ Exploration } & PC & Average number of patent/copyright for 3 years \\
\hline & & RDAL & Average number of R\&D agreement for 3 years \\
\hline & & MARF & Average number of first product/service to market for 3 years \\
\hline & \multirow{3}{*}{$\begin{array}{l}\text { User role } \\
\text { (USERTT) }\end{array}$} & USERRD & Scale of lead user role in innovation \\
\hline & & USEREA & Scale of early adopter role in innovation \\
\hline & & USERFD & Scale of user feedback in innovation \\
\hline \multirow{3}{*}{$\begin{array}{l}\text { Control } \\
\text { variable }\end{array}$} & R \& D activity & RDINT & Average $R$ \& D intensity for 3 years \\
\hline & Firm age & AGE & Age of a firm \\
\hline & Concentration ratio & HHI & Herfindahl-Hirschman index \\
\hline
\end{tabular}

The Pearson's correlation and VIF (variance inflation factor) results of variables are shown in Table 2. 
Table 2. Summary of coefficient of correlation and VIF (variance inflation factor).

\begin{tabular}{|c|c|c|c|c|c|c|c|c|c|c|c|c|c|c|}
\hline & VIF & HHI & RDINT & AGE & RDAL & PC & MARF & LIC & IMPS & MARAL & USERIT & USERRD & USERFD & USEREA \\
\hline HHI & 2.44 & 1.000 & & & & & & & & & & & & \\
\hline RDINT & 2.12 & 0.172 & 1.000 & & & & & & & & & & & \\
\hline AGE & 1.78 & $-0.203 *$ & $-0.337^{* * *}$ & 1.000 & & & & & & & & & & \\
\hline RDAL & 2.87 & -0.011 & -0.025 & -0.112 & 1.000 & & & & & & & & & \\
\hline PC & 2.31 & 0.043 & 0.114 & -0.051 & 0.044 & 1.000 & & & & & & & & \\
\hline MARF & 2.55 & -0.072 & 0.0191 & -0.098 & 0.162 & $0.266^{* *}$ & 1.000 & & & & & & & \\
\hline LIC & 2.67 & 0.109 & -0.009 & 0.111 & 0.093 & $0.214^{*}$ & 0.011 & 1.000 & & & & & & \\
\hline IMPS & 1.34 & -0.09 & -0.083 & $0.305^{* *}$ & 0.041 & -0.011 & 0.137 & 0.007 & 1.000 & & & & & \\
\hline MARAL & 2.03 & -0.033 & 0.005 & 0.066 & 0.160 & -0.102 & 0.054 & $0.247^{*}$ & -0.05 & 1.000 & & & & \\
\hline USERTT & 2.98 & 0.100 & -0.008 & -0.052 & $0.323^{* *}$ & 0.044 & 0.035 & $0.208^{*}$ & -0.003 & 0.082 & 1.000 & & & \\
\hline USERRD & 2.86 & 0.020 & -0.117 & 0.115 & $0.319^{* *}$ & 0.135 & 0.015 & $0.258^{* *}$ & 0.055 & 0.224 * & $0.039 * *$ & 1.000 & & \\
\hline USERFD & 3.32 & -0.005 & -0.07 & 0.033 & $0.326^{* *}$ & -0.166 & 0.051 & 0.060 & 0.052 & 0.214 * & 0.122 & 0.272 ** & 1.000 & \\
\hline USEREA & 3.13 & -0.015 & 0.020 & 0.06 & $0.264 * *$ & -0.008 & 0.138 & 0.035 & 0.016 & 0.17 & $0.485^{* *}$ & $0.213^{*}$ & $0.355^{* *}$ & 1.000 \\
\hline
\end{tabular}




\section{Results}

We used Model 1 to test the impact of using the user (USERTT) as a strategy. As expected in Table 3 , the user had a positive and significant impact on the average sales growth rate $(\beta=3.464, \rho=0.10)$. The effects of the other independent variables for MARF and LIC were positive and significant, while PC was negative and significant in both models. The number of patents and copyrights was the output of innovation, but it did not seem to be related to commercialization. As expected, the results of Model 1 provide empirical evidence supporting the positive relationship between the existence of user roles and firm growth. Model 2 was used to test the impact of detailed user roles USERRD, USEREA, and USERFD. The results showed that not all types of users helped to grow the firm. The user as a feedback provider was negative and statistically significant $(\beta=-29.108, \rho=0.05)$.

Table 3. Regression analysis results.

\begin{tabular}{|c|c|c|c|c|}
\hline \multirow[t]{2}{*}{ Var } & \multicolumn{2}{|c|}{ Model 1} & \multicolumn{2}{|c|}{ Model 2} \\
\hline & Coef. & Std. Error & Coef. & Std. Error \\
\hline $\mathrm{HHI}$ & -0.011 & 0.002 & -0.017 & 0.002 \\
\hline RDINT & $0.508^{*}$ & 0.296 & 0.472 * & 0.281 \\
\hline AGE & -0.761 & 0.661 & -0.992 & 0.653 \\
\hline RDAL & -0.116 & 10.003 & 2.195 & 9.5 \\
\hline PC & $-25.915^{* *}$ & 9.448 & $-33.23^{* * *}$ & 9.462 \\
\hline MARF & $19.399 * *$ & 6.47 & $19.594^{* * *}$ & 5.771 \\
\hline LIC & 21.481 * & 10.394 & $22.006^{* *}$ & 9.667 \\
\hline IMPS & -0.068 & 0.091 & -0.072 & 0.09 \\
\hline MARAL & -1.831 & 10.41 & -3.804 & 10.194 \\
\hline USERTT & 3.464 * & 2.025 & & \\
\hline USERRD & & & $18.869^{* *}$ & 9.466 \\
\hline USERFD & & & $-29.108^{* *}$ & 20.14 \\
\hline USEREA & & & $17.177^{* *}$ & 8.585 \\
\hline R-squared & \multicolumn{2}{|c|}{0.3746} & \multicolumn{2}{|c|}{0.4423} \\
\hline
\end{tabular}

The external factor, market concentration, was confirmed not to have a meaningful correlation with firm performance. The cause was inferred that the smart media industry is configured with layers, hardware, contents, software, and network firms. Thus, each layer has a different market concentration. On the other hand, it was identified that the internal factor was not correlated with firm performance. However, R\&D concentration had a positive correlation, with a value of 0.472 .

The analysis value was 22.006, supporting Hypothesis 1 and showing a positive correlation with performance. This implied that industry characteristics, shortened innovation and product cycles, and contents and software were immediately effective on firm performance. As claimed first in Chesbrough [1], inside-out innovation is helpful to performance. In the exploration strategy, patent and copyright had a negative correlation and first product on the market had a positive correlation with performance. This result supported Hypothesis 5. Licensing-out, categorized in the exploitation strategy as inside-out open innovation, increased firm profit by transferring internal resources to outside.

Empirical analysis showed that the integrated user role and separated user role had a correlation with performance. This result supported Hypothesis 7, and Step 2 supported Hypotheses 8 and 9. The leading user role improved firm performance, as mentioned earlier. Furthermore, early adopters influenced the majority of the early and late period by extending products and services to the majority, which positively influenced performance. 


\section{Discussion and Conclusions}

In this study, we divided the factors affecting the performance of firms in the smart media industry into internal and external factors, firm strategies, and user roles. The analysis showed that the relationship between internal and external factors and performance has a positive correlation with $R \& D$ activities and performance. For content and software firms, $R \& D$ activities have a positive impact on performance because they can secure a competitive edge by continually launching content by predicting user needs and demands. On the other hand, the market structure and performance of firms showed no significant results. This could be interpreted to mean that the degree of competition and monopolistic power differs according to the type of industry the smart media firm belongs to, as shown in the basic statistics survey.

In addition, firm age and performance were not significant. In the smart media industry, content and software companies are typically relatively new start-ups compared to the manufacturing industry, and there are diverse members, so the result was different from the relationship between age and performance in existing industries.

Second, we confirmed that the exploitation and exploration strategy of a firm is proportional or inversely proportional to the firm's performance. The layers that make up the smart media industry consist of hardware firms, network service providers, content and software providers, and consumers $[7,17]$. However, as indicated by the characteristics of the target firms, the majority of smart media firms are young, an average of 10 years, which makes it difficult to accumulate knowledge and experience of various businesses, and most of them are small and medium businesses, except network service providers. In these situations, outbound open innovation, such as license sales, is beneficial to firm performance [26], and the increase in simple patent and copyright development was in contrast to R\&D activities and market-first products or services, which were positively correlated with performance. This had a negative effect on performance.

In addition, having the first product on the market was positive for firm performance. The smart media industry based on ICT technology is characterized as a high-tech industry, which shows that innovation through exploration is positive for firm performance [38].

Third, we looked at the relationship between user roles and performance in the smart media industry. From a holistic viewpoint, user roles positively influenced firm performance. However, when studying user roles separately, each role influenced performance differently. First, leading users had a positive correlation with firm performance. User innovation with leading user expands the diversity of products by replacing the firm's role that finds the needs of customer. Mass production emerged to satisfy diverse and capricious customer needs, whereas modern customers expect customized products or services to suit their needs, at higher cost. Therefore, when user innovations are adopted and extended to customers, the diversity of products increases without depending solely on firms. In this regard, the leading user role reveals its purpose in the smart media industry. The emergence of a smart society allows an environment where users can be directly involved in development. User toolkits make a user-friendly environment, which helps individual users to innovate $[37,51]$ and broadens their freedom to do so. Additionally, the positive correlation of the early adopter role and firm performance was confirmed. Content and software have characteristics of information; through usage and evaluation, the reliability is tested, which leads to immediate feedback on products and services.

One of the user roles, feedback provider, had a negative correlation with firm performance. In the past, understanding and analyzing customers' needs and predicting demand was the responsibility of firms, and firms exercised that responsibility to develop, produce, and sell new products [52]. In other words, when firms reflect user feedback, they must also consider the quality of users. Furthermore, in some cases, products fail to meet customers' needs, although those needs were reflected at the product planning level, because customers' needs keep changing [53]. This is a characteristic of information resources, short product lifecycles, and a fast development timeframe, making it hard to predict customers' needs at the moment of market release. 
As discussed above, user roles influence firm performance; firms must understand and utilize their users in their strategies. The resources and capabilities of users and firms are complementary, not competitive [51]. Therefore, firms can replace or supplement deficient resources and capability by utilizing users.

For that reason, the first significant contribution of this research is the analysis of factors that affect firm performance in the newly developed yet unexplored smart media industry. Second, this research added the changing roles of users in the smart media industry to the analysis, and showed that such changes can be used to replace or supplement company strategies, unlike the existing model of research and innovation, which focuses only on one user role. Therefore, user innovation has the potential to replace the product development, $R \& D$, and dissemination stages. In the changing environment, user roles provide a new perspective for company strategy by replacing and assisting with resources and abilities.

The limitation of this research was that there were only a few prior studies on segmented user roles. Additionally, this research did not collect an accurate sample of firms, because the survey barely included network service providers. In addition, there may have been a lack of representativeness of the analysis results based on the sample data $(13 \%)$ of target firms. This is a limitation of survey-based research, and it will be necessary to increase the coverage of target firms in future research. In future research, the technological convergence phenomenon and horizontal changing of layers in the smart media industry will be studied. Furthermore, searching and selecting objective indicators of user roles will clearly prove the influence of user roles. These indicators will expand the range of this research and provide a deeper analysis of the smart media industry.

Author Contributions: Conceptualization, C.N. and E.K.; data curation, C.N.; formal analysis, C.N.; investigation, C.N.; methodology, C.N. and E.K.; project administration, E.K.; software, C.N.; supervision, E.K.; validation, E.K. and K.S.; writing — original draft, C.N.; writing—review and editing, E.K. and K.S.

Funding: This study has supported by Innopolis Foundation grant funded by the Korea government (MSIT) (No. 2019-DD-SB-0202-01), and by Medical Research Information Center (MedRIC) through the National Research Foundation of Korea (NRF), funded by the Ministry of Science and ICT of Korean Government (NRF No. 2018-R1-A6-A6040880).

Conflicts of Interest: The authors declare no conflict of interest.

\section{References}

1. Chesbrough, H.W.; Vanhaverbeke, W. Open Innovation: Researching a New Paradigm; Oxford University Press: New York, NY, USA, 2006.

2. Hwang, J.; Kim, E.; Kim, S. Factors affecting open technological innovation in open source software companies in Korea. Innov. Manag. Policy Pract. 2009, 11, 279-290. [CrossRef]

3. Jung, H.; Kim, E.; Kim, S.; Hwang, J. How diversification affects innovation by a Korean mobile content firm. Int. J. Mob. Commun. 2012, 10, 521. [CrossRef]

4. Kim, H.; Kim, E. How an Open Innovation Strategy for Commercialization Affects the Firm Performance of Korean Healthcare IT SMEs. Sustainability 2018, 10, 2476. [CrossRef]

5. Kodama, F.; Shibata, T. Beyond fusion towards IoT by way of open innovation: An investigation based on the Japanese machine tool industry 1975-2015. J. Open Innov. Technol. Mark. Complex. 2017, 3, 23. [CrossRef]

6. Shim, S.-O.; Park, K.; Choi, S. Sustainable Production Scheduling in Open Innovation Perspective under the Fourth Industrial Revolution. J. Open Innov. Technol. Mark. Complex. 2018, 4, 42. [CrossRef]

7. Kim, E.; Lee, D.; Kim, J.H. How collaboration networks affect innovation in Korea's information and communication technology industry in the era of Internet of Things. Asian J. Technol. Innov. 2016, 24, $202-221$. [CrossRef]

8. Grosse, M.; Pohlisch, J.; Korbel, J.J. Triggers of Collaborative Innovation in Online User Communities. J. Open Innov. Technol. Mark. Complex. 2018, 4, 59. [CrossRef]

9. Kim, E.; Bae, K.; Rim, M.; Lee, D. Developing and Evaluating New ICT Innovation System: Case Study of Korea's Smart Media Industry. ETRI J. 2015, 37, 1044-1054. [CrossRef] 
10. Della Corte, V.; Iavazzi, A.; D'Andrea, C. Customer involvement through social media: The cases of some telecommunication firms. J. Open Innov. Technol. Mark. Complex 2015, 1, 10. [CrossRef]

11. Han, M.; Wu, J.; Wang, Y.; Hong, M. A Model and Empirical Study on the User's Continuance Intention in Online China Brand Communities Based on Customer-Perceived Benefits. J. Open Innov. Technol. Mark. Complex. 2018, 4, 46. [CrossRef]

12. Han, J.; Cho, O. Platform business Eco-model evolution: Case study on KakaoTalk in Korea. J. Open Innov. Technol. Mark. Complex. 2015, 1, 6. [CrossRef]

13. Von Hippel, E. Democratizing Innovation; The MIT Press: Cambridge, MA, USA, 2005.

14. He, Z.-L.; Wong, P.-K. Exploration vs. Exploitation: An Empirical Test of the Ambidexterity Hypothesis. Organ. Sci. 2004, 15, 481-494. [CrossRef]

15. Kim, S.; Kim, H.; Kim, E. How knowledge flow affects Korean ICT manufacturing firm performance: A focus on open innovation strategy. Technol. Anal. Strat. Manag. 2016, 28, 1-15. [CrossRef]

16. Bento, F. Complexity in the oil and gas industry: A study into exploration and exploitation in integrated operations. J. Open Innov. Technol. Mark. Complex 2018, 4, 11. [CrossRef]

17. Na, C.; Kim, E.; Hwang, J. Research on open innovation strategy and its performance in Korea smart media industry: Focusing on user innovation strategy. In Proceedings of the 20th ITS Biennial Conference, Rio de Janeiro, Brazil, 30 November-3 December 2014.

18. Fransman, M. Innovation in the new ICT ecosystem. Martin Fransman's the New ICT Ecosystem: Implications for Europe, Forthcoming. In Proceedings of the 20th ITS Biennial Conference, Bangkok, Thailand, 2-3 April 2009.

19. Cohen, W.M.; Levinthal, D.A. Absorptive Capacity: A New Perspective on Learning and Innovation. Adm. Sci. Q. 1990, 35, 128. [CrossRef]

20. Shin, K.; Lee, D.; Shin, K.; Kim, E. Measuring the Efficiency of U.S. Pharmaceutical Companies Based on Open Innovation Types. J. Open Innov. Technol. Mark. Complex. 2018, 4, 34. [CrossRef]

21. Lee, J.H.; Kim, E.; Sung, T.-E.; Shin, K. Factors Affecting Pricing in Patent Licensing Contracts in the Biopharmaceutical Industry. Sustainability 2018, 10, 3143. [CrossRef]

22. Kim, S.Y.; Kim, E. How Intellectual Property Management Capability and Network Strategy Affect Open Technological Innovation in the Korean New Information Communications Technology Industry. Sustainability 2018, 10, 2600. [CrossRef]

23. Gulati, R.; Singh, H. The Architecture of Cooperation: Managing Coordination Costs and Appropriation Concerns in Strategic Alliances. Adm. Sci. Q. 1998, 43, 781. [CrossRef]

24. Shin, K.; Kim, E.; Jeong, E. Structural Relationship and Influence between Open Innovation Capacities and Performances. Sustainability 2018, 10, 2787. [CrossRef]

25. Ahuja, G. Collaboration Networks, Structural Holes, and Innovation: A Longitudinal Study. Adm. Sci. Q. 2000, 45, 425. [CrossRef]

26. Lee, I.; Kim, E. Factors Affecting the Outbound Open Innovation Strategies in Pharmaceutical Industry: Focus on Out-Licensing Deal. J. Open Innov. Technol. Mark. Complex 2019, 5, 73. [CrossRef]

27. Bhatt, P.; Altinay, L. How social capital is leveraged in social innovations under resource constraints? Manag. Decis. 2013, 51, 1772-1792. [CrossRef]

28. Altinay, L.; Saunders, M.N.; Wang, C.L. The influence of culture on trust judgments in customer relationship development by ethnic minority small businesses. J. Small Bus. Manag. 2014, 52, 59-78. [CrossRef]

29. Chathoth, P.K.; Ungson, G.R.; Altinay, L.; Chan, E.S.; Harrington, R.; Okumus, F. Barriers affecting organisational adoption of higher order customer engagement in tourism service interactions. Tour. Manag. 2014, 42, 181-193. [CrossRef]

30. Bunt, L.; Harris, M.; Westlake, S. Schumpeter Comes to Whitehall; NESTA: London, UK, 2010.

31. Castro, L.M.; Montoro-Sánchez, Á.; Ortiz-De-Urbina-Criado, M. Innovation in services industries: Current and future trends. Serv. Ind. J. 2011, 31, 7-20. [CrossRef]

32. Hsueh, J.-T.; Lin, N.-P.; Li, H.-C. The effects of network embeddedness on service innovation performance. Serv. Ind. J. 2010, 30, 1723-1736. [CrossRef]

33. Alves, H. Co-creation and innovation in public services. Serv. Ind. J. 2013, 33, 671-682. [CrossRef]

34. Von Hippel, E. Open Source Software Projects as User Innovation Networks; The MIT Press: Cambridge, MA, USA, 2002. 
35. Morrison, P.D.; Roberts, J.H.; Von Hippel, E. Determinants of User Innovation and Innovation Sharing in a Local Market. Manag. Sci. 2000, 46, 1513-1527. [CrossRef]

36. Rogers, E.M. Lessons for Guidelines from the Diffusion of Innovations. Jt. Comm. J. Qual. Improv. 1995, 21, 324-328. [CrossRef]

37. Von Hippel, E. Economics of product development by users: The impact of "sticky" local information. Manag. Sci. 1998, 44, 629-644. [CrossRef]

38. Rothaermel, F.T.; Deeds, D.L. Exploration and exploitation alliances in biotechnology: A system of new product development. Strat. Manag. J. 2004, 25, 201-221. [CrossRef]

39. Yamakawa, Y.; Yang, H.; Lin, Z. (John) Exploration versus exploitation in alliance portfolio: Performance implications of organizational, strategic, and environmental fit. Res. Policy 2011, 40, 287-296. [CrossRef]

40. Blonigen, B.A.; Taylor, C.T. R\&D intensity and acquisitions in high-technology industries: Evidence from the US electronic and electrical equipment industries. J. Ind. Econ. 2000, 48, 47-70.

41. Levin, R.C.; Cohen, W.M.; Mowery, D.C. R\&D appropriability, opportunity, and market structure: New evidence on some Schumpeterian hypotheses. Am. Econ. Rev. 1985, 75, 20-24.

42. Lee, Y.J.; Shin, K.; Kim, E. The Influence of a Firm's Capability and Dyadic Relationship of the Knowledge Base on Ambidextrous Innovation in Biopharmaceutical M\&As. Sustainability 2019, 11, 4920.

43. Koza, M.P.; Lewin, A.Y. The Co-Evolution of Strategic Alliances. Organ. Sci. 1998, 9, 255-264. [CrossRef]

44. Bierly, P.E.; Daly, P.S. Alternative Knowledge Strategies, Competitive Environment, and Organizational Performance in Small Manufacturing Firms. Entrep. Theory Pr. 2007, 31, 493-516. [CrossRef]

45. Lettl, C. User involvement competence for radical innovation. J. Eng. Technol. Manag. 2007, $24,53-75$. [CrossRef]

46. Riggs, W.; Von Hippel, E. Incentives to innovate and the sources of innovation: The case of scientific instruments. Res. Policy 1994, 23, 459-469. [CrossRef]

47. Jeppesen, L.B.; Molin, M.J. Consumers as Co-developers: Learning and Innovation Outside the Firm. Technol. Anal. Strat. Manag. 2003, 15, 363-383. [CrossRef]

48. March, J.G. Exploration and Exploitation in Organizational Learning. Organ. Sci. 1991, 2, 71-87. [CrossRef]

49. Sorensen, J.B.; Stuart, T.E. Aging, Obsolescence, and Organizational Innovation. Adm. Sci. Q. 2000, 45, 81. [CrossRef]

50. Osborn, R.N.; Baughn, C.C. Forms of Interorganizational Governance for Multinational Alliances. Acad. Manag. J. 1990, 33, 503-519.

51. Henkel, J.; Von Hippel, E. Welfare Implications of User Innovation. J. Technol. Transfer 2004, 30, $73-87$. [CrossRef]

52. Shah, S. Sources and Patterns of Innovation in a Consumer Products Field: Innovations in Sporting Equipment. 2000. Available online: http://opensource.mit.edu/papers/shahsportspaper.pdf (accessed on 11 September 2007).

53. Dahan, E.; Hauser, J.R. The virtual customer. J. Prod. Innov. Manag. 2002, 19, 332-353. [CrossRef]

(C) 2019 by the authors. Licensee MDPI, Basel, Switzerland. This article is an open access article distributed under the terms and conditions of the Creative Commons Attribution (CC BY) license (http://creativecommons.org/licenses/by/4.0/). 